\title{
Persuasion Strategies: Musicians, Music and Theater (in the Archives of Two Spanish-American Cities) ${ }^{1}$ Estrategias de persuasión: músicos, música y teatro (en los archivos de dos ciudades latinoamericanas)
}

\section{Hugo Hernán Ramírez Sierra}

Universidad de los Andes

COLOMBIA

huramire@uniandes.edu.co

[Hipogrifo, (issn: 2328-1308), Volumen extraordinario, 1, 2018, pp. 121-139]

Recibido: 14-11-2017 / Aceptado: 24-11-2017

DOI: http://dx.doi.org/10.13035/H.2018.extra01.09

Abstract. Studies on music of the Conquest and the Colonial Period in Spanish America usually favor information obtained from ecclesiastical sources or about religious topics while frequently neglecting other sources and documents which would allow assumptions about the relationship between music and the development of the earliest Spanish-American theater. To question this behavior, in the first part, I comment on some data related to the Archive of the Town Council of the City of Mexico, an outstanding secular source as it records a great deal of data about Spanish music in sixteenth-century Mexico. In the second part, I comment on a jácara kept in the archives of the Cathedral of Bogota, which is interesting because the popular character of the composition goes beyond what is strictly liturgical.

Keywords. Music, Conquest, Colonial Period, Mexico, Colombia.

1. This work is part of project FFI2014-52007-P, Authority and Power in the Theatre of the Golden Age. Strategies, genres, images in the first globalization, Ministry of Economy and Competitiveness, Government of Spain. Directorate General of Scientific and Technical Research. National Programme for Fostering Excellence in Scientific and Technical Research. This paper is also in the context of an ongoing research project about history of theatre in Latin American in sixteen and seventeenth centuries. See in the bibliography, for example, Ramírez 2009 or Ramírez 2015. 
Resumen. Los estudios sobre música de la Conquista y el período colonial en Hispanoamérica generalmente favorecen la información obtenida de fuentes eclesiásticas o sobre temas religiosos, mientras que a menudo descuidan otras fuentes y documentos que permitirían proponer hipótesis sobre la relación entre la música y el desarrollo del teatro hispanoamericano más antiguo. Para cuestionar este comportamiento, en la primera parte, comento algunos datos relacionados con el Archivo del Ayuntamiento de la Ciudad de México, una fuente secular sobresaliente que registra una gran cantidad de datos sobre la música española en el México del siglo XVI. En la segunda parte, comento una jácara guardada en los archivos de la catedral de Bogotá, interesante porque el carácter popular de la composición va más allá de lo estrictamente litúrgico.

Palabras clave. Música, conquista, período colonial, México, Colombia.

The uses of music that are evoked by Lope in the Arte Nuevo de hacer comedias (1609) and the transformation registered by Cervantes in the prologue of his Comedias and entremeses (1615) collection, have their reference point in sixteenth century theater, both European and Latin-American. In Seville or in Mexico, in Toledo or in Lima, in Segovia or in Santafé, the Autos Sacramentales, carriages and stages developed, if not identically, at least in parallel, especially in the last third of the sixteenth, as well as during the seventeenth century. On both sides of the Atlantic, subjects, characters or authors were recognized and on both sides of the Atlantic such recognition was linked, among other things, to the spread of the music that accompanied them in theatrical presentations.

In most cases, when carrying out historical studies about music during the Conquest and the Colonial Period in Spanish America, the ecclesiastical archives and topics related to religious activity attract attention. It could not be otherwise: the Church was perhaps the most important authority in the region, as it regulated the use of many of the topics and stored a great deal of musical production. Such control has made ecclesiastical archives a privileged source when addressing the issue of the spread of music: from classical studies by Robert Stevenson (1959), for instance, on music in Peru to the most recent by Lourdes Tourrent (2003) on La Conquista musical de Mexico, this dissemination and ecclesiastical archives have walked hand in hand.

Without intending to question the role of the Church as a driving force behind much Spanish-American theater in the Conquest and Colonial periods, I find that the preponderance of religion has favored a certain kind of documentary resources (the ecclesiastical archive) and consequently neglected, for example, secular sources (town hall and notary records, account books, letters, etc.). For the same reason, favoring religious sources has meant that many documented testimonies, whose key feature is mockery or satire ${ }^{2}$, remain unnoticed.

2. Obviously, the exception confirms the rule: see for instance the paper by Davis and Varey (2003) on the notary of Madrid Juan García de Albertos or the book by Méndez and Baudot (1997) on the documents of the Inquisition. 
I shall first comment on some data associated with a secular source, the Actas del Archivo del Cabildo de la Ciudad de Mexico ${ }^{3}$, which is important because much of the data about Spanish music in $16^{\text {th }}$ century Mexico was recorded there. Secondly, I shall comment on a jácara kept in the Archivo Musical de la Catedral de Bogota ${ }^{4}$, which interests me because of the popular nature of the composition and because it exceeds what is strictly religious. It is pertinent to mention that my interest in music from the $16^{\text {th }}$ and $17^{\text {th }}$ centuries is related to its use in theatrical contexts and because I consider that music is one of the key avenues for the study of the origins of Spanish-American theater.

\section{THE ARCHIVE OF THE CABILDO OF MEXICO}

On June 8, 1692, American Indians, Creoles and Spaniards rebelled in Mexico City. The frequent increases in corn prices were intolerable. The issue would not be important for us if not for the fact that the place where the archives of Mexico were kept began burning amidst the turmoil. Seeing the town hall on fire, the mathematician and historian Carlos de Sigüenza paid to rescue the town hall records and hundreds of other papers. The papers saved by Sigüenza are the current archives of the Cabildo of Mexico of the $16^{\text {th }}$ and $17^{\text {th }}$ centuries. The documents in these archives show that beyond the relationship between music and missionary activity or between music and its liturgical use, it is possible to point out that music gradually became a centerpiece as part of celebrations and theater in New Spain ${ }^{5}$. In general terms, the civil archives of Mexico offer administrative information on the contracts of musicians, participation in civil celebrations, organization of dance and singing schools, manufacturing of instruments, salaries, censorships and fines, etc.

When referring to the arrival of Spanish musicians in America, it is worth highlighting that they came to towns which, almost always, saw the cultural value of music. Aside from the fact that in pre-Columbian societies music had a ritual function, and that melodies, songs and dances played a key role in their festivities, what must be highlighted here is that European musicians were an important part in the process of forming and recognizing cities as new Renaissance strongholds. Just as the conquest of Mexico began, Fray Toribio de Benavente registered, for example, the arrival of «menestriles de Castilla que pasaron a estas tierras» who taught music and stated «que lo que estos yndios naturales deprendieron en dos meses, no lo deprendían en España españoles en dos años porque en dos meses cantaban muchas misas, Magnificat y motetes»?. In that sense, the blossoming of spaces devoted to music must be attributed both to the growing number of musicians who had come from Spain and to the intense musical training offered to the

3. I quote in the text with ACM and the date of each act.

4. I will quote following the edition by Perdomo (1976).

5. For the relationship between musicians and the emerging theatrical activity in 16th-century Mexico, see Ramírez, 2009, pp. 77-83.

6. Sahagún, Historia general de las cosas de Nueva España, pp. 129 and following

7. Motolinía, Memoriales, p. 341 
natives in missionary schools. Newly arrived musicians turned emerging cities not only into stages where Spanish musical practices associated with Christian liturgy were transmitted, but also into an environment in which the enhancement of musical arts boosted the flourishing of other artistic manifestations such as dance and theater.

Through the chroniclers, we know there were professional musicians accompanying the expeditions by Cortés and by Pánfilo de Narváez. Regarding Cortés, Bernal Díaz stated that

mandó Cortés tocar el atanbor a [Fulano de] Canillas, que ansí se llamaba nuestro atanbor, y a Benito de Begel, nuestro pífano, que tocase su tamborino, e mandó a Gonzalo de Sandoval, que era capitán y alguacil mayor, para que llamase a todos los soldados y comenzásemos a marchar ${ }^{8}$.

On Narváez, the Historia verdadera indicated that:

los atabaleros que el Narváez traía, comenzaron a tocar los atabales e a tañer sus pífanos y tamborinos, y decía: '¡Viva, viva la gala de los romanos, que siendo tan pocos han vencido a Narváez y a sus soldados!'. E un negro que se decía Guidela, que fue muy graçioso truhán, que traía el Narváez, daba boces y decía: 'Mirá que los romanos no han hecho tal hazaña'. Y por más que les decíamos que se callasen y no tocasen sus atabales, no querían hasta que Cortés mandó que prendiesen al atabalero, que era medio loco y se decía Tapia9.

Accounts by chroniclers and town hall records allow us to show that the conquerors were accompanied by individuals whose main activity was performing with musical instruments but who, due to the historical process which was occurring, were obliged to change their activity slightly by the administration. The Mexico City Municipal Council records bear witness to the development of music and show that in Mexico, as in all the Hispanic territories, dissemination is not only an external manifestation of cult, but also, for example, a commercial activity associated with buying and selling a service, a public activity that granted certainly a social recognition to those who performed it, and even an activity destined not just for churchgoers but mainly for crowds, as the entity was in a process of formation.

The records of the Cabildo of Mexico are filled with references to musicians hired for civil and religious celebrations and with news regarding the 'players' who had just arrived in the city. In the records there are musicians who ask to perform in a particular place; trumpet or tambourine players who hire themselves for feasts, processions and parades; artists who perform as dance instructors, and singing coaches and teachers who live as artisans devoted to the manufacture of musical instruments. Table 1 (Examples of the Actas del Cabildo de Mexico) shows a small sample of the kind of document found in the archives of the Cabildo and allows

8. Díaz, Historia verdadera de la conquista de la Nueva España, p. 317.

9. Díaz, Historia, p. 332. 
us to see that the presence of musicians in $16^{\text {th }}$-century Mexico had at least three stages: first some individuals who, on their own behalf, introduced an activity into Mexico (document 1), then some groups paid to take part in the celebrations organized in the city (documents 2, 3 and 4) and finally, "professional" comedians associated with the development of new Spanish theater who were hired to use music in the shows (documents 5, 6,7 and 8).

One of the first musicians who appears in the Actas del Cabildo and in the chronicles is Benido de Begel who arrived with Cortés, but who had been a fife, tambourine and drum player for the emperor's armies in Italy ${ }^{10}$. Begel was granted a license to build «una escuela de danzar por ser ennoblecimiento de la ciudad» ${ }^{11}$. The impact of this dance school is uncertain, but months later Begel appeared before the notary Juan Fernández del Castillo, first to rent his school to Alonso Hernández de Herrera and later to acknowledge a debt due to his participation in the expedition to the Hibueras. In fact, on June 12, 1527, Begel stated «adeudar a Martín de Berrío, vecino de la misma ciudad, 17 pesos y 4 tomines de oro, "de resto de una silla jineta, que recibí comprada [...] del maestre Francisco Roche, trepador, en el camino que veníamos de las Hibueras, e a vos el dicho Martín de Berrío os pertenecen, para en cuenta e pago de ciento sesenta pesos de oro que el dicho maestro Francisco Roche os debe" $\rangle^{12}$. The dance school and agencies for players were located near the old street of Empedradillo, today Guatemala, which were independent facilities governed by city regulations and not by the guilds ${ }^{13}$.

Documents 2, 3 and 4 show the presence of musicians who were involved in several activities associated with institutional changes or with attempts to consolidate a kind of 'colonial stability' in New Spain: one of the fundamental traits of this stability was the fact that the celebrations in Mexico were based on Spanish fiestas. In Mexico the arrival of the king in one place or another was celebrated, as was military activity or the emperor's diplomacy, and newly arrived neighbors all rejoiced with social news coming from the Iberian Peninsula.

In all these cases, the Cabildo was prepared to make the investments considered convenient and, in every case, the success of the musicians was directly proportional to the success of the city as a whole. Finding musicians for every fiesta, embellishing them with liveries, hiring black musicians or teaching music to the children of indigenous noblemen are expressions of the same purpose. When the conquerors brought in institutions such as the Church, notaries or the Cabildo, it could be said that music almost always accompanied them; trumpet and tambourine players complemented every Saint Hippolytus parade and every Corpus Christi procession, the ordinances were preceded by the drum beat ${ }^{14}$, Epiphany or Our Lady festivities or Santiago or Saint Sebastian days implied coral arrangements to sing

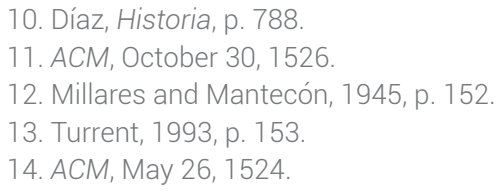


the octaves, the eves or the solemnities ${ }^{15}$; in masses for the deceased, the requiem was sung with the highest solemnity. Musicians were also present in welcoming or farewell parties; their presence was essential and their absence could be taken as an offense.

The importance of musicians in parades was such that the first strike to be registered in the city is the so-called trumpet 'strike', whose strongest strategy to exert pressure was the musicians' refusal to take part in a parade to honor the Inquisition ${ }^{16}$.

The process against the trumpet players was mentioned by Alfonso Toro when studying the presence of Jews in New Spain ${ }^{17}$; according to Toro, during the procedures to install the tribunal of the Holy Office, on June 6, 1536, Friar Juan de Zumárraga put on trial two trumpet players who refused to play in the solemnities of such an event carried out at Nuestra Señora Hospital (Jesus hospital). According to Toro, the trumpet players had a fair reason not to play their instruments since they had not been paid for the announcements for the feast day of the feared tribunal, and nonetheless the arrogant inquisitor condemned them to imprisonment and a fine ${ }^{18}$.

From his arrival in Mexico, Zumárraga had shown his concern because the faith shown in religious celebrations was not completely authentic or because the liturgical acts could be contaminated with touches of Judaism by those who had recently arrived or with idolatry by the natives. If the hierarch persecuted musicians, such harassment was an expression of his attempts to control and censor suspicious behavior, both Spanish and native ${ }^{19}$.

On the other hand, the trumpet players' strike had a more complex background associated with the fact that the musicians had outstanding social mobility. In fact, instrument manufacturers were not associated in a guild and charged important sums for their services. Those benefits gave musicians a sort of privileged case or social recognition. In a recent piece of research about everyday life in $16^{\text {th }}$ century Mexico, the following is stated about the musicians:

Mantener a este grupo era gravoso para las comunidades y suscitaba preocupación en las autoridades eclesiásticas quienes - según una Real Cédula de 1561 - así se expresaban de ellos: «son grandes holgazanes... y destruyen las mu-

15. ACM, August 31,1531

16. Turrent, 1993, p. 154 and Moreno, 1972, pp. 9-10.

17. Toro, 1932, pp. 3-5.

18. Toro, 1932, p. 3

19. Zumárraga's concern to maximize control was also seen when in the Junta Eclesiástica held in 1539, he defined regulations about processions or when, in 1544, he promoted the translation and dissemination of Dionisio Rckel's Manual de procesiones. Ramos Smith, 1998, pp. 240 and following, and Rivera, 2006, pp. 100-102. 
jeres casadas y doncellas, y hacen otros vicios anexos a la ociosidad en la que se han criado» ${ }^{20}$.

In the Cabildo of Mexico there are several documents that register, at least for this city, the problems of musicians and their social mobility. On December 12, 1583 it was requested that «Juan Velazquez de Salazar prosiga en las negociaciones para que se les quiten prerrogativas a los curas y cantores de la Iglesia de la Ciudad, por ser contrarias a los vecinos, porque se considera excesivo lo que llevan de derechos en enterramientos y honras». Another example of the growing autonomy of musicians in Mexico is found in a document dated in 1593 which shows the benefits that came for a native when performing a musical activity. The text, originally written in Náhuatl and kept in the Archivo General de la Nación in Mexico, states that the Jesuit Juan de Sandoval, in charge of the Colegio de San Gregorio, knew that some of his pupils had to carry out heavy task, reason why he presented a complaint and a request. A paragraph of the text translated by Luis Reyes García reads as follows:

hemos educado a algunos de nuestros hijos aquí en Mexico, les hemos enseñado canto y música de viento para que nos ayuden los domingos y en las grandes fiestas, en la prima y en las vísperas. Y ahora los tlailacalleque de San Sebastián y de San Pablo los quieren sacar para que hagan el couatequitl y el cemilhuatequitl como les va tocando y si esto así se lleva a cabo será en deservicio de nuestro señor Dios y de la ley divina. Esto es lo que proponemos, ayúdalos y ordena a los merinos y a los tepixque para que no les den el trabajo de couatequitl. No son muchos nuestros hijos de los de San Sebastián, sólo son siete ${ }^{21}$.

The names of Indian natives who sang and played wind instruments and by doing so were exempt from having to undertake heavy demolition duties are: Francisco Lázaro, Pedro de la Torre, Gaspar Xuárez, Francisco Martín, Martín Alonso, Francisco Juan and Mateo Sánchez.

Documents 5, 6, 7 and 8, show the development of theatrical activity as such. As a result of the data we have about theatrical plays in the second half of the $16^{\text {th }}$ century both in Mexico and in Spain, we now know that musicians always took part; they accompanied the floats in the processions, stood behind the stage, and only towards the end of the period we are analysing, did they enter the stage. It seems that going on stage meant their disappearance from the Actas del Cabildo de Mexico. As a matter of fact, when the records start to make references to floats, stages and comedies, the allusions to the musicians start to disappear or, in the best-case scenario, they are subordinated to the performance of one comedy or the other, to being hired by one author or another, to the censorship of a piece of work or another.

20. Escalante and Rubial, 2005, p. 382. The image of the tambourine player associated with that of a slightly unacceptable individual is included in the Diccionario de Autoridades where the following sentence is recorded «he traído los atabales» to mean that «uno es bellaco, socarrón, y que de nada se altera y espanta».

21. Reyes García, 1996, pp. 316-317 
However, due to the enormous importance of musicians in the life of the city during the $16^{\text {th }}$ century and owing to the control exerted by the Church on their activity, it is possible today to infer the payroll of the musicians hired and controlled by the Church along with the year they were hired: Juan Suárez (1539), Pedro de Guevara (1548), Melchor Téllez (1550), Juan de Cervantes (1552-1555), Lázaro del Álamo (1556), Juan de Vitoria (1570), Hernando Franco (1575)22. Also, due to ecclesiastical control, fashion trends at the time and the book trade, the wages of the most performed authors can be deduced: Francisco de Peñalosa, Pedro de Escobar, Francisco de la Torre, Cristóbal de Morales, Tomás Luis de Victoria, Francisco Guerrero and Giovanni Pierluigi23.

It is harder to define the most common repertoires for this period, although there might have been - as assumed by Margit Frenk- an association between ancient Spanish music and recent New Spanish lyrics. The hypothesis of the association between music and lyrics implies, on one hand, that many of the New Spanish songs were sung with Spanish vocal music, adapting new lyrics to well-known compositions ${ }^{24}$. On the other hand, the hypothesis of the association of melodies and lyrics may imply that music composed in Mexico was used to accompany Spanish songs that arrived, for instance, through romance and song books that had been dispatched to America as soon as the conquest began ${ }^{25}$ and that in most cases came with their authors: it should not be forgotten that through Mexico passed such authors as Gutiérrez de Cetina (in 1547), Juan de la Cueva (between 1574 and 1577) and Eugenio de Salazar (between 1581 and 1599).

The Cabildo records say nothing about the repertoire, but what is certain is that the musical repertoire that we can find for $16^{\text {th }}$ century Mexico is restricted to a few pieces on which there is no clear certainty. Margit Frenk says:

Es verdad que en la Nueva España se originaron durante el virreinato libros de música, manuscrita e incluso impresa; pero, aparte de los que contienen música instrumental y de los de carácter teórico, se trata de obras de canto llano y de otras que contienen polifonía litúrgica, por supuesto con texto en latín. Fuera de la polifonía litúrgica, lo que se ha conservado de la polifonía vocal son chanzonetas en lengua vulgar, villancicos religiosos dedicados a celebrar, sobre todo, la Navidad y el Corpus Christi. Los componían y dirigían los maestros de capilla y también las monjas músicas de los conventos; los cantaban los coros de niños de las iglesias y los colegios de indios. Sobreviven muy pocos villancicos polifónicos del siglo dieciséis pero se conservan un número creciente a partir de comienzos del siglo diecisiete ${ }^{26}$

Perhaps one of the places where those collections of music books are best stored and give us an idea about the repertoire are the archives of the cathedral ca-

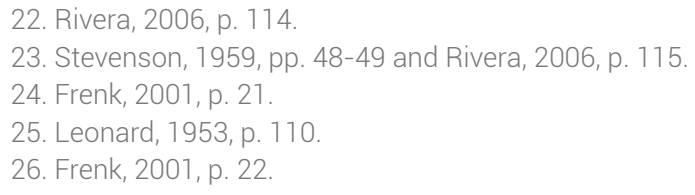


bildos not only in Mexico, but also in cities with lesser lineage such as Santafé de Bogota.

\section{A JÁCARA FROM THE ARCHIVES OF BOGOTA}

Since not all the cities in Spanish America shone as did Mexico City, when consulting the archives of other capital cities, we must bear in mind the differences between them. For instance, to document the spread of music in Nueva Granada (an area of land which corresponds approximately to what is currently Colombia, Ecuador, Venezuela, and Panama), it is worth remembering that while the conquest of Mexico happened early on (1519-1521) and its colonization was relatively fast, in Nueva Granada the conquest occurred later (Europeans first arrived in Bogota 20 years after their arrival in Mexico City), and the application of many institutions also occurred later (for example, the printing press arrived in Mexico in 1539 whereas it did not arrive in Bogota until 1738).

Despite the differences, all the American colonies were influenced from an early stage by Spanish music for several reasons: because it was associated with military activity, because it was part of religious activity or because it was a factor of social distinction. Aside from the reasons for the arrival of the first European musicians, what is certain is that there are currently areas which have been studied in depth, while studies about other areas are scarce ${ }^{27}$.

Regarding the case of Colombia, the first testimonies about the dissemination of music also come from chroniclers. Juan de Castellanos in his Elegía de varones ilustres evoked passages of well-known ballad: «el juramento del marqués de Mantua»

27. From Peru, for instance, thanks to the papers by Robert Stevenson, we know the key role the Actas Capitulares play as a documentary source, as well as the use given to the «libros de canto de órgano» from an early moment (Stevenson, 1959, p. 66). Based on these two sources, Stevenson showed data about patrons, artists, works and salaries in Peru. Accordingly, regarding the period we are dealing with, he showed that in 1553, Juan Solano, Bishop of Cusco, presented the first and the second part of the masses by Cristóbal de Morales, along with other polyphonic books with «Misas, Magnificads, cuatro cancioneros de motetes de canto de órgano» (Stevenson, 1959, p. 66); that in 1580 Pedro Serrano was hired as «ministril de xeremia y corneta» with a salary of 500 pesos a year, though two years later the cathedral cabildo found that Serrano «no es avil para lo que se le obligó y no ha cumplido lo que prometió» (Stevenson, 1959, p. 68). The Actas Capitulares also leave testimony that Gonzalo de Mora (1585), Luis Enríquez (1589) and Gaspar de Villagrás (1593) were hired for in the 16th century. There are less studied cases such as Venezuela, which also have left evidence of their special peculiarities. For example, one of the first testimonies about music in Venezuela was left by a German who went through the city of Coro and kept a detailed record of his expedition in a badly written chronicle -printed in an even worse manner, which was published in UIm in 1557 and which is kept in the university library of Tübingen. Nicholas Federmann, the chronicler, tells that when Ambrosious Dalfinger retook the Governor's office of Venezuela, after the failed expedition in which a hundred Christians and a similar number of Indian natives had died, the acting governor, Hans Seissenhofer (known in other chronicles as Juan Alemán), arranged a welcoming party with «una bien dispuesta parada de las gentes de a caballo y de a píe, a media milla de la ciudad de Coro, bajo una tienda de campaña, con misa cantada y Te Deun Laudamus, al son de tambores y de trompetas» (Federmann, Indianische Historia, p. 37). See Palacios, 2000. 
$(1,11,5)^{28}$, «Marqués de Montesclaros» $(2,1)$, «Romance de Gómez Farías» $(3,10)$, «Gaiferos» (3-10), the ballads «Mira Nero de Tarpeia» $(1,14,4)$ and «Mis arreos son las armas» $(1,1,2$ y 1, 5,2 y 1, 10, 5), or the «Romance del tiempo bueno» $(2,4,4)$.

Along with these ballads, Castellanos evoked the use of music in the conquest and even indicated some of the most well-known authors, amongst whom he included Bartolomé Fernández de Virués, Jorge de Herrera, Fernán Mateos and Diego de Miranda.

\author{
Allí también dulcísimo contento \\ De voces concertadas en su punto, \\ Cuyos concentos lleva manso viento \\ A los puntos oídos por trasunto: \\ Corre mano veloz el instrumento \\ Con un ingenioso contrapunto, \\ Enterneciéndose los corazones \\ Con nuevos villancicos y canciones. \\ Porque también Polihimnía y Erato, \\ Con la conversación del duro Marte, \\ De número sonoro y verso grato, \\ Tenían deste tiempo buena parte: \\ Rara facilidad, suave trato, \\ Y en la composición ingenio y arte, \\ De los cuales discípulos y alumnos \\ Podríamos aquí decir algunos \\ Y aun tú que sus herencias hoy posees, \\ No menos preciarás saber quién era \\ Bartolomé Fernández de Virués, \\ $Y$ el bienquisto Jorge de Herrera: \\ Hombres de más valor de lo que crees, \\ Y con otros también de aquella era, \\ Fernán Mateos, Diego de Miranda, \\ Que las musas tenían de su banda $(1,14,1)$.
}

By the end of the $16^{\text {th }}$ century, Juan Rodríguez Freyle in his El Carnero stated that in 1568 it was founded «(en Bogota) un colegio seminario, con título de San Luis, en el cual se sustentaban diez y ocho colegiales, con sus ropas pardas y becas azules, a cargo de su Rector, que era un clérigo viejo y virtuoso, el cual les enseñaba canto llano y canto de órgano» ${ }^{29}$. Around the same time, we learn of the arrival in Carora (Venezuela) of the vihuela player, musician and dance teacher Jorge Voto, who «puso escuela y comenzó a enseñar a los mozos del lugar; y siendo ya más conocido, danzaban las mozas también» ${ }^{30}$. Voto found himself involved in a series of crimes which made him move first to Pamplona, in the north of Colombia and then to Tunja, in the central region of the same country.

28. Within the parentheses are shown the book, section and song. Gisela Butler's (1969) book presents a detailed analysis of these ballads in the context of Nueva Granada.

29. Rodríguez, 1979, pp. 231-232.

30. Rodríguez, 1979, p. 22. 
Aside from Voto's anecdote, the important thing is to remember that both in America and in Spain musicians -as well as many of the recently arrived Europeans- used to move from town to town when work or life conditions looked better elsewhere. Natural-born adventure lovers at heart, musicians also did so carrying instruments, books, and knowledge which they used wherever they saw the opportunity. Some of the musicians who traveled through what is now Colombia were ${ }^{31}$ :

- Juan Pérez Materano (arrived in Cartagena de Indias in 1537 and died there on November 27, 1561).

- Gonzalo García Zorro (first musician born in Santafé 1548, son of a conqueror and a niece of cacique Tisquesusa died in 1617).

- Alonso Garzón de Tahuste (born in Timaná in 1558 and died in Santafé de Bogota in 1654).

- Gutiérrez Fernández Hidalgo (he is known to have been in Bogota circa 1556 and to have died circa 1620).

- José Cascante (died in December, 1702).

- Juan de Herrera (chapel master from January16, 1702 to March 18, 1738).

Musicians of the cathedral chapel, choir boys, instrument players and singers were cathedral workers and obviously had access to some of the music books introduced by the archbishops of the city since 1549.

In the case of Bogota, the archives safeguard hundreds of examples of lyrical compositions with different meters called ensaladas, sad songs called endechas and romances (or the Spanish ballads) sung and musically adapted in that city by members of the religious orders, students of Jesuit schools or by ordinary citizens. I would now like to focus on a document of the archives of the cathedral as a sample of the kind of heterodox documents kept in this archive. It is a jácara (comic ballad of low life) whose music was composed by Juan Ximénez, but whose text appears to have come from $16^{\text {th }}$ century Spain. Juan Francisco Ximénez de Alarcón who apparently belonged to a family of musicians settled in Santafé de Bogota and likely to have been a partner of Juan Concha, who was a «cathedral musician, trumpeter, second organ player, in charge of the instruction in tiple» ${ }^{32}$. In May 1687 he was hired as a musician and organ player for the Cathedral of Bogota, and in the music archives of the cathedral are eight Christmas carols signed simply as Juan Ximénez. ${ }^{33}$ We equally know that in 1701 he was a joint advocate for Father Joseph de Cascante, who was in charge of the music scene during the second half of the $17^{\text {th }}$ century in Nueva Granada ${ }^{34}$.

When commenting on the jácara composed by Juan Ximénez kept in the Archives of the Cathedral of Bogota, we must take into account not only the characteristics and the evolution of this genre but also its place in the setting of the Golden Age

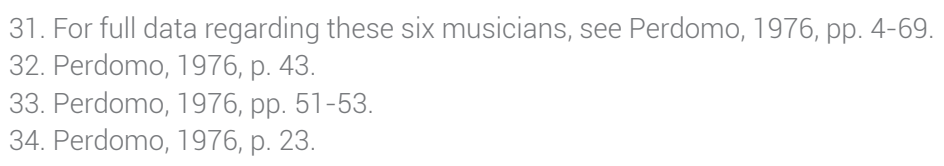


theatrical feast. The jácara is a brief festive piece accompanied by music and dance which initially seems to have been performed by a single individual, but, as time passed, a set of players who surprised and made audiences laugh was added to it. Since the jácara appeared at the end of the comedy and immediately after the dance, apparently the musketeers, the nosiest area of the audience, cried «jácara, jácara» and one or several actors started a short performance which, in theory, was not part of the program. According to Javier Huerta Calvo ${ }^{35}$, since the jácara was prepared by the actors, on some occasions, they mingled with the audience and were the ones who encouraged the presentation of the act. A recent paper about the brief Spanish theater, when talking about the jácara, advised that «no hay que olvidar, sin embargo, que la jácara se originó del tono con el que los músicos aliviaban la impaciencia del auditorio mientras se acomodaba en sus asientos, por lo que se cantaba al inicio de los espectáculos y, como arriba hemos dicho, también al fin» ${ }^{36}$.

In general terms, the main characters of the jácaras are ruffians, devout woman, students or soldiers who construct dialogues full of jokes and non-sense, and they are marked by the use of underworld slang, much of which was used in a literary manner by Quevedo and Cervantes. For Cotarelo ${ }^{37}$, the jácara was a genre that progressively lost ground as a result of its burlesque tone and an alleged sophistication of theatrical audiences. Perhaps the evolution of the genre, the scarcity of witness accounts (if compared to other genres), its fossilization and later disappearance have more to do with the closeness of the jácara to dance, the high degrees of improvisation and the loss of distinction between the former and the higher deal of commotion related to the latter ${ }^{38}$.

The example I present has to do with that description and could have been staged both at the end of a liturgical celebration or as a part of some kind of liturgical procession or act belonging to Christmas time. Let us take into account the fact that in much of Spanish America, activities such as the Mexican posadas, in which Christmas time is an excuse for popular celebrations, have been common since colonial times. On the other hand, a warning must be made that although the music associated with this text is attributable to a composer of the early $17^{\text {th }}$ century, it is very possible that the lyrics belong to an old Spanish composition and that Ximénez merely rewrote a previously known text.

The students' jácara is clearly divided into three sections: an initial refrain, some variations associated to that refrain and fifteen couplets devoted to introducing the characters of the jácara. Concerning the initial refrain, this is an invitation to the

\footnotetext{
35. Huerta Calvo, 1985, pp. 55-58.

36. Buezo and Plaza, 2008, p. 94.

37. Cotarelo, 1911, p. CCLXXXVII.

38. In any case, it is convenient to point out that despite being known during the Golden Age, Jácara does not appear as an entry either in Covarrubias' Tesoro de la lengua, or in the Autoridades, and that it was only included in the dictionary in 1818 when it was defined, amongst other things as «la junta de muzuelos y gente alegre que de noche anda metiendo ruido y cantando por las calles. Adolescentium cantanium turba nocturna».
} 
feast which, without saying who the main characters are, offers a clue through the macaronic uses of Latin.

\author{
Estribillo: \\ Afuera plaza, \\ hagan lugar, \\ dejenle entrar: \\ atollite cum gatorum \\ musicorum, plaza! \\ ñau, gurruñau, \\ dejen entrar.
}

Those who perform the refrain certainly play amidst the audience wearing hats or caps that suit their condition. The reason for the meowing immediately recalls Lope de Vega's Gatomaquia in which a small burlesque poem portrays the war between the armies of Mizifuz and Marramaquiz. Another oblarged precursor of the allusion to the cats is found in the Libro de los gatos, the medieval exempla where human behavior is censored or praised through examples using cats or mice. The use of animals as part of a jácara is really not new, at least if we take into account the fact that Sebastián Rodríguez de Villaviciosa has a jácara called «Baile de los conejos ${ }^{39}$ in which the image of the animal helps to define the picaresque character of the work using slang.

In our jácara, cats are not only an excuse to scratch the features of several characters who appear in the couplets and to build some easy rhymes with onomatopoeia. The use of macaronic Latin in this part seems to be related to the fact that the jácara was presented by students of late $16^{\text {th }}$-century Bogota and to the need to mold some decidedly prudish characters. On this issue, it is worth pointing out that Covarrubias records the entry 'mojigato' to refer to the «hombre que está muy disimulado y callado, humilde, esperando la ocasión para hacer su hecho, como hace el gato cuando está esperando que salga el ratón; de manera que está compuesto por mus, que vale ratón, y gato, con esta alusión y similitud». I have recalled this entry since the attacks the students make in their couplets aim specifically at three characters representing three social groups traditionally characterized by prudery: The bald man, the pander and the sacristan.

Regarding the variations associated with the refrain, they are clearly very common parallel structures in popular poetry between the $15^{\text {th }}$ and $16^{\text {th }}$ centuries as can be seen, for instance, in the Corpus collected by Margit Frenk. The variations start in every case with a text in macaronic Latin that serves as an interjection point for the three sections. The verses in 'Latin' are followed by the development of the topic 'dejen entrar' past the gates, as understood by watching the baby who will certainly be awoken by the noise made by the students shouting and the cats meowing in the onomatopoeias. 


\begin{tabular}{|l|l|l|}
\hline atollite famossorum & Atollite tu portalem & famossum \\
graduatorum, plaza! & benitorum, plaza! & quatorum. \\
Que un canto violencia & Que una música nueba y gatuna & Afuera plaza, \\
los muebe celebrar, & viene esta noche & atollite \\
la gente oirlos cantar: & rabiando al portal: & quatrialbus \\
dejen entrar; & plaza, dejen entrar, & estudiantorum \\
quien viene, quien va?, & afuera, dejen entrar, & per omnia saecula \\
entren todos y el niño & porque en tropa caminan & seculorum. \\
que llora con ese grasejo, & yllegan los cuatro estudiantes & Plaza y atollite, \\
podrán callar, & con fiestas y solas; & dejen entrar, \\
y a cuantos & quien es, quien ba? & yerbum caro \\
el sueño vencido hubiere, & entren todos & sin oír mas \\
despierten los gatos & y al niño que llora & razones, \\
con su maullar, & echen los gatos \\
ñau y ñau, & con ese grasejo, & cum gatorum \\
dejen entrar. & podrán acallar: & mussicorum, tu \\
& plaza, hagan lugar, & portamen. \\
\hline
\end{tabular}

The variations appear only as an introduction for the final entrance of the couplets which are definitely the core of the jácara, the most formally elaborate passage which is loaded with irony.

The fifteen couplets are divided thematically into four moments: three couplets to introduce the student actors (1-3), three couplets for a bald man (4-6), six couplets for a pander (7-12) and three couplets for a sacristan (13-15).

In the first set, we have the introduction of the four naughty students and their load of cats. Here it is worth highlighting the pun granted to Christmas Eve, not only as a Christmas night, but as a night appropriate for partying. The image of the students is associated with the golden patterns of their big hats (because of their clothes), the defense (for the tests) and the humiliation (due to the later celebration of achieving an academic degree).

Quatro estudiantes gorrones
con quatro gatos a questas,
caminan para el portal
por tener la nochebuena.
En calabazas los traen
con las cabezas de fuera,
porque no puedan usar
de las garras en defensa.
Y en picarezca algazara
los estudiantes vozean,
dando vejamen a todos
con diversas chanzonetas.

The second set of stanzas turns the bald man into the butt of jokes because he has no hair and because of his similarity to one who has no money. The bald man is 
one who has lost what he had but strives to regain his condition, though to do so he cannot make use of his own means. The bald man's efforts are useless; he needs the opportunity provided by others. In this sense, the allusion to the bald man as a Calvinist is not only an incidental word play, but also the description of the Calvinist, as one who entirely depends of other person's will to be saved.

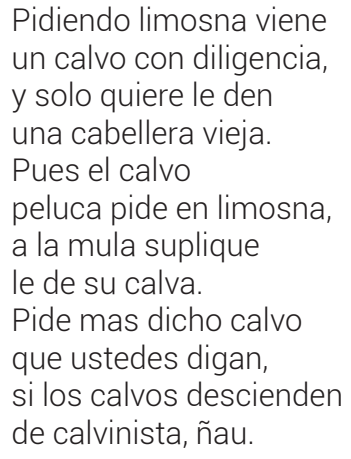

The third and biggest set of couplets is devoted to the pander. She is introduced with various features proper to her character: devout, beggarly, toothless, etc. The jácara emphasizes first on the fact that it is a woman who cannot find her own place in society and who asks to be admitted as a duenna (a widow wearing a nun's wimple). Immediately after, the jácara reduces the request of the woman to a merely economic issue which can be solved if she returns to her duties as a fortune teIler; in fact, the claim to come and see the child is based on the child's helping her to solve a escrúpulo (a doubt). At the end of the section devoted to the old woman, her physical image is compared to the tarasca (monstrous big mouthed snake) which in the Middle Ages and the Golden Age accompanied the Corpus Christi procession and whose monstrous proportions are emphasized by using the bull's horns as a toothpick.

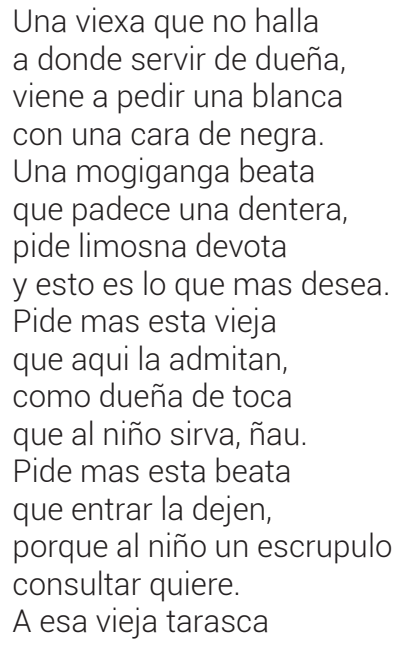




\author{
despachen luego, \\ que no es fiesta de corpus \\ el nacimiento. \\ Dele el buey a la beata \\ lo que pretende, \\ tendrá en sus linternas \\ dos mondadientes.
}

In the last set of couplets there is the figure of the sacristan as a prude, a cuckold, willing to have the bull's contract.

\author{
Por venir tan al cabo \\ del villancico, \\ le darán de limosna \\ del Buey, los sirios. \\ Porque le agan algún bien \\ un sachristán clamorea, \\ y esto con mil humildades \\ mas no con alma sincera. \\ Pide mas el sachristán \\ que al buey supliquen, \\ su contrato le preste \\ para un vinete.
}

Students, bald men, duennas and sacristans are characters associated with folklore and used by popular poetry, minor theater and the picaresque. Though I cannot precisely date Juan Ximénez's jácara, what I wish to highlight is that the text kept in the archives of the cathedral of Bogota represents a late form of dissemination of Spanish theatrical tradition and the musical element in it performed by an author of the $17^{\text {th }}$ century must have been part of the same tradition.

The research carried out in archives of two Spanish American cities allows us to state that in $16^{\text {th }}$ century Mexico and in $17^{\text {th }}$ century Bogota, music was developed thanks to the introduction of European lyrics, instruments and musical techniques not only as a consequence of the religious men's work, but also principally due to the presence of real waves of musicians who arrived on the continent. The musicians left testimony of their arrival in music scores and account books, in civil records such as the Actas del Cabildo de Mexico and in religious collections such as the Archivo de la Catedral de Bogota. In Mexico, they progressively added music, dance and singing to the theatrical show, in Bogota, they were hired as chapel masters or minstrels, they had a place in the choir or composed jácaras and villancicos (Christmas carols); what is important is that in both places, they exceeded the limits imposed by what was strictly religious, they helped transform churchgoers into audiences and founded Spanish American colonial theater. 


\section{Table 1. Examples of the Actas del Cabildo de México}

\begin{tabular}{|c|c|}
\hline Topic & Date and transcription \\
\hline $\begin{array}{l}\text { 1. Arrangement of } \\
\text { sites }\end{array}$ & $\begin{array}{l}\text { October } 30,1526 \text { : Request for a site made by Maese Pedro and Benito } \\
\text { de Begel to build a dance school where the square lies now, for it would } \\
\text { increase the nobility of the city. They were given license to make a } 50 \text {-foot } \\
\text { long and } 30 \text {-foot wide building. And they asked the aforementioned to } \\
\text { be obliged to the city for such a rent. They were given a } 40 \text {-peso rent per } \\
\text { month. }\end{array}$ \\
\hline $\begin{array}{l}\text { 2. Fiestas of the } \\
\text { conquerors }\end{array}$ & $\begin{array}{l}\text { August } 11,1533 \text {. The trumpet players of the city were paid } 30 \text { pesos of } \\
\text { gold for having served in the alegrias of welcome to his Majesty to the } \\
\text { kingdoms of Castille and for the feasts of Saint Hippolyte [patron saint of } \\
\text { Mexico City]. }\end{array}$ \\
\hline $\begin{array}{l}\text { 3. Victories of the } \\
\text { emperor }\end{array}$ & $\begin{array}{l}\text { May } 7,1545 \text {. It was agreed to celebrate the victory and peace with } \\
\text { France on Pentecost, with alegrias, bull running and juegos de cañas, } \\
\text { competitions in which the participants threw long rods at each other } \\
\text { and from which they guarded themselves with shields. The majordomo } \\
\text { was sent to buy, from his own purse, five loads of clothes to be dyed in } \\
\text { the colors provided to make the liveries for the gentlemen and to have } \\
\text { trumpets and tambourines bought, if necessary. }\end{array}$ \\
\hline $\begin{array}{l}\text { 4. Musicians in the } \\
\text { viceroyal city }\end{array}$ & $\begin{array}{l}\text { March } 7,1551 \text {. Appointment of the second lieutenant to take out } \\
\text { the banner for the feast for Saint Hyppolite to the regidor Alonso de } \\
\text { Villanueva and payment to this latter in the form of a reward for such a } \\
\text { day equivalent to } 25 \text { pesos of gold nuggets and } 12 \text { of tepuzque intended } \\
\text { for trumpets and tambourines. He was commanded to make liveries } \\
\text { and to have them dyed, some in green and orange and others in orange } \\
\text { and white, for } 80 \text { gentlemen, due to the Paseo del pendón and that the } \\
\text { majordomo paid the expenses caused from the assets of the city. }\end{array}$ \\
\hline $\begin{array}{l}\text { 5. Musicians and } \\
\text { poets }\end{array}$ & $\begin{array}{l}\text { July } 8,1560 \text {. Juan Velázquez de Salazar requested granting a jewel to } \\
\text { Hernando de Terrazas worth } 100 \text { pesos of gold as a rewarding to pay for } \\
\text { the trumpet and tambourine players, because the latter wanted to write in } \\
\text { metrics to praise Saint Hyppolite. }\end{array}$ \\
\hline $\begin{array}{l}\text { 6. Floats and } \\
\text { processions }\end{array}$ & $\begin{array}{l}\text { July } 15,1575 \text {. It was agreed that Diego Juárez be granted } 50 \text { pesos for } \\
\text { the play to be performed on Corpus Christi Day featuring four floats on } \\
\text { which the actors recited Corpus Christi pieces [...] On the second float, the } \\
\text { fall of man was recited with certain interludes. } \\
\text { July } 15,1577 \text {. A } 25 \text {-peso prize was awarded Juan de Valladolid for having } \\
\text { performed the best play of the cocolistle on the floats on Corpus Christi day. }\end{array}$ \\
\hline 7. Stages and dances & $\begin{array}{l}\text { June } 4,1592 \text {. It was ordered that the new comedy Bachiller Arias de } \\
\text { Villalobos be performed at the Corpus Christi celebration, as long as it did } \\
\text { not exceed the cost of } 1000 \text { pesos of common gold. It was also ordered } \\
\text { that a master mason should build the stage, it was ordered that a dance } \\
\text { of gypsies and one of Portuguese dancers or of some other sort be } \\
\text { performed at the Corpus Christi celebration. }\end{array}$ \\
\hline 8. Comedies & $\begin{array}{l}\text { September 4, 1594. Jerónimo López and Guillen Brondat ask for } 2000 \\
\text { pesos to buy clothing, velvet of Castille, golden fabrics and whatever } \\
\text { was needed for Gonzalo Riancho to be able to stage the comedies which } \\
\text { would be shown on Corpus Christi and on the eighth. It is ordered to bring } \\
\text { the obligation from previous years that Riancho had with the city to see it. }\end{array}$ \\
\hline
\end{tabular}




\section{BIBLIOGRAPHY}

Actas del Cabildo de la Ciudad de México, ed. Ignacio Bejarano, México, Municipio Libre, 1889.

Beutler, Gisela, Studien zum spanischen Romancero in Kolumbien in seiner schriftlichen und mündlichen Überlieferung von der Zeit der Eroberung bis zur Gegenwart, Heidelberg, Winter, 1969.

Buezo, Catalina and Nuria Plaza Carrero, «Tipología de las formas breves», in Historia del teatro breve en España, dir. Javier Huerta Calvo, Madrid/Frankfurt, Iberoamericana/Vervuert, 2008, pp. 63-119.

Castellanos, Juan de, Elegías de varones ilustres de Indias, ed. Gerardo Rivas Moreno, Bogotá, Villegas, 1997.

Cienfuegos Antelo, Gema, «Villaviciosa», in Historia del teatro breve en España, dir. Javier Huerta Calvo, Madrid/Frankfurt, Iberoamericana/Vervuert, 2008, pp. 386-399.

Cotarelo y Mori, Emilio, Colección de entremeses, loas, bailes, jácaras y mojigangas desde fines del siglo XVI a mediados del XVIII, Madrid, Nueva Biblioteca de Autores Españoles, 1911.

Davis, Charles and John E. Varey, Actividad teatral en la región de Madrid según los protocolos de Juan Garcia de Albertos, 1634-1660, Estudio y documentos, London, Tamesis, 2003.

Díaz del Castillo, Bernal, Historia verdadera de la conquista de la Nueva España, ed. José Antonio Barbón Rodríguez del manuscrito Guatemala, México, El Colegio de México/DAAD/Universidad Nacional Autónoma de México/Ministerio de Asuntos Exteriores de España/Cooperación Española, 2006.

Federmann, Nicolaus, Indianische Historia, ed. Juan Friede, München, Renner, 1965.

Frenk, Margit. «Poesía y música en el primer siglo de la colonia», in La otra Nueva España. La palabra marginada en la colonia, coord. Mariana Masera, Barcelona, Azul/Universidad Nacional Autónoma de México, 2001, pp. 17-39.

García Icazbalceta, Joaquín, Don fray Juan de Zumárraga, primer obispo y arzobispo de México, México, Porrúa, 1947.

Huerta Calvo, Javier (dir.), Teatro breve: de los siglos XVI y XVII; entremeses, loas, bailes, jácaras y mojigangas, Madrid, Taurus, 1985.

Leonard, Irving, Libros del Conquistador, México, FCE, 1953.

Méndez, María Águeda and Georges Baudot, Amores prohibidos: La palabra condenada en el México de los virreyes. Antología de coplas y versos censurados por la Inquisición de México, Mexico, Siglo XXI, 1997. 
Millares Carlo, Agustín and Juan Ignacio Mantecón, Índice y extractos de los Protocolos del Archivo de Notarías de México (1524-1528), México, El Colegio de México, 1945.

Motolinia, Fray Toribio de Benavente, Memoriales (libro de oro, MS JGI 37), ed. Nancy Joe Dyer, México, El Colegio de México, 1996.

Moreno, Salvador, «Huelga de Trompetas», Diálogos, 48, 1972, pp. 9-10.

Palacios, Mariantonia, Noticias musicales en los cronistas de la Venezuela de los siglos XVI-XVIII, Caracas, Fundación Vicente Emilio Sojo/Fondo Editorial de Humanidades y Educación/Universidad Central de Venezuela, 2000.

Perdomo Escobar, José Ignacio, El archivo musical de la Catedral de Bogotá, Bogotá, Instituto Caro y Cuervo, 1976.

Ramírez, Hugo Hernán, Fiesta, espectáculo y teatralidad en el México de los conquistadores, Madrid/Frankfurt/México, Iberoamerican/Vervuert/Bonilla Artigas, 2009.

Ramírez, Hugo Hernán (ed.), Una fiesta teatral en la Nueva Granada del siglo XVII, Madrid/Frankfurt, Iberoamericana/Vervuert, 2015.

Ramos Smith, Maya, Censura y teatro novohispano, 1539-1822: ensayos y antología de documentos, México, Consejo Nacional para la Cultura y las Artes, 1998.

Reyes García, Luis, Eustaquio Celestino Solís, Armando Valencia Ríos, Constantito Medina Lima and Gregorio Guerrero Díaz, Documentos nauas de la ciudad de México del siglo dieciséis, México, CIESAS/Archivo General de la Nación, 1996.

Rivera, Octavio, Recursos teatrales en el fasto y la representación teatral en Nueva España en el siglo dieciséis, thesis of doctorate not published, México, El Colegio de México, 2006.

Rodríguez Freyle, Juan, El Carnero, ed. Darío Achury Valenzuela, Caracas, Biblioteca Ayacucho, 1979.

Sahagún, Bernardino de, Historia general de las cosas de Nueva España, México, Consejo Nacional para la Cultura y las Artes, 2002.

Stevenson, Robert, The Music of Peru. Aboriginal and Viceroyal Epochs, Washington, D.C., Pan American Union/General Secretariat, Organization of American States, 1959.

Stevenson, Robert, «La música en el México de los siglos XVI al XVII», en La música en México, ed. Julio Estrada, México, Universidad Nacional Autónoma de México, 1986, pp. 7-74.

Toro, Alfonso (comp.), Los judíos en la Nueva España, México, Archivo General de la Nación/FCE, 1932.

Turrent, Lourdes, La conquista musical de México, México, FCE, 1993. 
